Economics Development Analysis Journal 7 (4) (2018)

\title{
Analisis Guncangan (Shock) ASEAN dalam Wacana Pembentukan Asean Currency Unit (ACU)
}

\section{Susi Susanti ${ }^{凶}$}

Jurusan Ekonomi Pembangunan, Fakultas Ekonomi, Universitas Negeri Semarang, Indonesia

\begin{tabular}{l} 
Info Artikel \\
\hline Sejarah Artikel: \\
Diterima Juli 2018 \\
Disetujui September 2018 \\
Dipublikasikan \\
November 2018 \\
\hline Keywords: \\
CPI, Real GDP, Vector \\
Error Correction Model \\
(VECM)
\end{tabular}

\begin{abstract}
Abstrak
Kawasan yang akan membentuk mata uang tunggal harus memiliki kriteria pola perdagangan yang sama, guncangan makroekonomi yang simetris dan kesamaan pembangunan ekonomi. Namun, masih terdapat ketimpangan dan instabilitas berbagai indikator ekonomi seperti GDP Riil, Indeks Harga Konsumen dan neraca perdagangan. Tujuan penelitian ini adalah melihat respon guncangan indikator ekonomi di ASEAN-10. Variabel yang digunakan dalam penelitian ini adalah Indeks Harga Konsumen (IHK), GDP Riil dan Neraca Perdagangan dari sepuluh negara ASEAN. Data yang digunakan dalam penelitian ini adalah data kuartalan dari tahun 2002 hingga tahun 2015. Metode yang digunakan adalah Vector Error Correction Model. Hasil penelitian menunjukkan bahwa korelasi perekonomian dari indikator Indeks Harga Konsumen (IHK), GDP Riil dan Neraca Perdagangan di ASEAN masih rendah. Respon goncangan dari negara-negara ASEAN terhadap goncangan yang terjadi di Singapura menunjukkan hasil yang bervariasi dan belum simetris. Hal ini menunjukkan bahwa syarat pembentukan mata uang tunggal belum terpenuhi. Hasil varian decomposition juga menunjukkan bahwa gejolak perekonomian Singapura masih dominan dipengaruhi oleh kondisi internal dalam negeri. Namun, varian decomposit GDP Rill menunjukkan bahwa Laos memiliki peranan lebih tinggi dibandingkan dengan Singapura yang disebabkan oleh hubungan kerjasama yang terjalin antara kedua negara tersebut.
\end{abstract}

\begin{abstract}
The region that will form a single currency must have the same trade pattern criteria, symmetrical macroeconomic shocks and similar economic development. However, ASEAN region are still imbalances and instability of various economic indicators such as real GDP, consumer price index and trade balance. The aims of study is see the shocks response of economic indicators in ASEAN-10. The variables used in this research are Consumer Price Index (CPI), Real GDP and Trade Balance from ten ASEAN countries. The data used in this study is quarterly data from 2002 to 2015. The method used is the Vector Error Correction Model. The results of study indicate that the economic correlation of indicator Consumer Price Index (CPI), Real GDP and Trade Balance in ASEAN is still low. The shock response from ASEAN countries to shocks that occurred in Singapore showed varying results and not symmetrical. This is shows that the requirement of formation of single currency has not been fulfilled. The result of the decomposition variant also shows that Singapore's economic turmoil is still dominantly influenced by internal conditions. However, the decomposition variant of GDP Rill shows that Laos has a higher role compared to Singapore due to the cooperative relationship between the two countries.
\end{abstract}

(C) 2017 Universitas Negeri Semarang

\footnotetext{
Alamat korespondensi:

Gedung L2 Lantai 2 FE Unnes

Kampus Sekaran, Gunungpati, Semarang, 50229

E-mail: edaj@mail.unnes.ac.id.
} 


\section{PENDAHULUAN}

Association of Southeast Asian Nations (ASEAN) dibentuk pada tanggal 8 Agustus 1967 yang pada awalnya terdiri dari lima negara yaitu Indonesia, Malaysia, Singapura, Thailand dan Filipina. Hingga pada tahun 1999, anggota ASEAN terus mengalami pertambahan hinggamenjadi sepuluh anggota. Menindaklanjuti ideintegrasi dalm suatu kawasan, sejak tahun 2015, ASEAN telah membentuk komunitas yaitu Asean Economic Community. Asean Economic Community adalah bentuk integrasi ekonomi regional dengan tujuan menjadikan Asean sebagai pasar tunggal dan basis produksi yang mana terjadi arus barang, jasa, investasi, tenaga kerja, serta aliran modal yang lebih bebas. Sektor-sektor yang menjadi prioritas MEA adalah pertanian, otomotif, elektronik, perikanan, produk kayu, transportasi udara, e-ASEAN, kesehatan dan pariwisata. (Kemendag, 2015). Pembentukan kerjasama ini dilatarbelakangi oleh salah satunya adalah Krisis Finansial Asia yang terjadi pada tahun 1998. Krisis yang terjadi merupakan krisis nilai tukar yang berasal dari Thailand dan kemudian menimbulkan contagion effect ke seluruh wilayah Asean. (Harahap,2013), Tindak lanjut dari integrasi ekonomi yang terjadi di Asean adalah pembentukan mata uang tunggal sesuai dengan visi ASEAN 2020. Pembentukan mata uang tunggal ini diharapkan dapat memudahkan transaksi dan stabilisasi sistem keuangan di ASEAN. Latar belakang pembentukan mata uang tunggal yaitu aliran modal masuk dan keluar di antar negara ASEAN telah terbuka. Suatu negara diberi kebebasan untuk berinvestasi dalam suatu negara lain. Selain itu, faktor pendorong dibentuknya mata uang tunggal yaitu kesuksesan mata uang Euro yang berhasil menjadi mata uang nomor dua di dunia dan menjadi alternatif ketika nilai dolar tidak stabil. (Falianty, 2006). Rose dalam Falianty (2006) mengatakan bahwa negara yang menjadi bagian dari currency union akan mengalami aliran perdagangan $100 \%$ lebih tinggi dibandingkan negara yang bukan anggota currency union.

Suatu wilayah yang akan membentuk mata uang tunggal harus memenuhi kriteria teori Optimum Currency Area (OCA). Teori ini mengatakan bahwa suatu ruang lingkup geografis yang optimal dengan satu jenis mata uang atau beberapa mata uang yang di peg secara permanen harus memenuhi kriteria tertentu. Kriteria tersebut diantaranya internal dan external factor mobility, upah dan tenaga kerja. (Mundell dalam Kusuma,2013)

Tabel 1. Indikator Ekonomi Asean

\begin{tabular}{llccc}
\hline No & Negara & $\begin{array}{c}\text { Nilai Tukar } \\
\text { thd Dolar (\%) }\end{array}$ & Inflasi (\%) & NP ( juta US\$ ) \\
\hline 1 & Indonesia & 0,34 & 8,4 & $-1.886,2$ \\
2 & Brunei Darussalam & $-2,88$ & $-0,2$ & $6.987,6$ \\
& & & & \\
3 & Singapura & -3.14 & 1,0 & $43.521,4$ \\
4 & Laos & 1,68 & 4,2 & $-109,0$ \\
5 & Kamboja & $-0,36$ & 3,9 & $-8.291,8$ \\
6 & Thailand & 1,58 & 1,9 & $-378,7$ \\
7 & Filipina & $-1,15$ & 4,2 & $-5.947,0$ \\
8 & Myanmar & $-4,76$ & 1,0 & $-5.195,4$ \\
9 & Vietnam & $-0,07$ & 4,1 & $2.405,9$ \\
10 & Malaysia & $-3,17$ & 4,2 & $25.076,9$ \\
\hline
\end{tabular}

Sumber : WDI, 2016 
Berdasarkan tabel 1, terdapat ketimpangan atau selisih yang cukup besar diantara negara-negara ASEAN. Indikator nilai tukar di ASEAN hampir semuanya mengalami depresiasi. Penguatan atau pelemahan nilai tukar dipengaruhi oleh keseimbangan perdagangan internasional dan pelaku bisnis. Indikator inflasi menunjukkan Indonesia mengalami inflasi yang sangat tinggi. Hal tersebut disebabkan oleh kondisi internal dalam negeri yaitu kebijakan menaikkan harga BBM bersubsidi yang berdampak terhadap kenaikan harga bahan pokok. Namun Brunei Darussalam justru mengalami deflasi atas kebijakan pengendalian inflasi dengan melakukan pegging terhadap dolar Singapura. Sedangkan indikator neraca perdagangan menunjukkan bahwa hampir semua negara ASEAN mengalami defisit neraca, kecuali Brunei Darussalam, Singapura, Vietnam dan Malaysia. Negara yang mengalami defisit neraca perdagangan menunjukkan ketergantungan yang tinggi pada impor luar negeri.

Tabel 2. ketimpangan GDP di Asean

\begin{tabular}{llll}
\hline No & Negara & 2010 & 2015 \\
\hline 1 & Brunei & 32.063 & 30.942 \\
& Darussalam & & \\
2 & Kamboja & 785 & 1.198 \\
3 & Indonesia & 2.977 & 3.357 \\
No & Negara & 2010 & 2015 \\
4 & Laos & 1.079 & 1.831 \\
5 & Malaysia & 8.772 & 9.657 \\
6 & Myanmar & 811 & 1.246 \\
7 & Filipina & 2.147 & 2.850 \\
8 & Singapura & 46.570 & 52.744 \\
9 & Thailand & 5.071 & 5.737 \\
10 & Vietnam & 1.338 & 2.109 \\
\hline
\end{tabular}

Sumber :Asean Statistical Yearbook,2015

Berdasarkan tabel 2, ketimpangan GDP perkapita di ASEAN sangat tinggi. Hal ini dilihat dari selisih GDP perkapita antar negara di ASEAN sangat jauh seperti halnya Singapura dan Brunei Darussalam yang tinggi dengan GDP perkapita Kamboja. Indikator pendapatan perkapita dapat menunjukkan tingkat kesejahteraan penduduk di negara tersebut.
Berdasarkan tabel 1.2 dapat diambil kesimpulan bahwa secara garis besar tingkat kesejahteraan penduduk di ASEAN sangat tidak seimbang.

Berdasarkan informasi dari tabel 1 dan 2, menunjukkan bahwa ketimpangan indikator makroekonomi diantara negara-negara ASEAN masih cukup besar. Berbagai upaya dilakukan oleh ASEAN untuk melindungi kerjasama regional di kawasan tersebut antara lain $A S E A N$ Economic Community, ASEAN Political Security Community dan ASEAN Socio Cultural Community. Sebelum membentuk komunitas AEC, ASEAN juga telah melakukan integrasi diantaranya yaitu PTA dan AFTA. Wacana pembentukan Asean Currency Unit bertujuan untuk memfasilitasi transaksi dan mempermudah integrasi di ASEAN. Namun, ketimpangan yang terjadi di ASEAN merupakan kendala dalam upaya pembentukan mata uang tunggal.

Berdasarkan latar belakang yang telah diuraikan, maka tujuan dalam penelitian ini adalah (1) untuk mengetahui respon goncangan (shock) variabel IHK di ASEAN-10, (2) untuk mengetahui respon goncangan (shock) variabel GDP Riil di ASEAN-10, (3) untuk mengetahui respon goncangan (shock) variabel neraca perdagangan di ASEAN-10, (4) untuk mengetahui wacana pembentukan Asean Currency Unit dapat diterapkan di ASEAN-10.

\section{METODE PENELITIAN}

Penelitian ini merupakan jenis penelitian kuantitatif. Jenis data yang digunakan adalah data sekunder dalam bentuk data kuartalan (quarterly time series) pada periode Januari 2002 sampai dengan Desember 2015. Variabel yang digunakan antara lain Indeks Harga Konsumen (IHK), Pertumbuhan GDP Riil dan Neraca Perdagangan.

Metode analisis yang digunakan dalam penelitian ini adalah Vector Error Correction Model (VECM) dengan menggunakan alat bantu E-Views 8. Uji yang harus dilalui dalam metode VECM antara lain Pengujian Pra-Estimasi yang terdiri dari uji akar unit/ uji stasioneritas, uji panjang lag, uji kointegrasi dan uji kausalitas granger. Setelah dilakukan uji pra estimasi, 
kemudian dilakukan uji VECM untuk melihat hubungan jangka pendek dan jangka panjang. (Setiawan dan Karsinah, 2016). Hubungan jangka panjang dan jangka pendek dilakukan pada variabel Indeks Harga Konsumen, GDP Riil dan Neraca Perdagangan. Setelah itu dilakukan uji impulse response function untuk melihat respon goncangan ASEAN terhadap goncangan yang terjadi di negara benchmark, Singapura. Selanjutnya, uji yang terakhit yaitu forecast error variance decomposition untuk melihat perbandingan besaran pengaruh dari masing-masing negara dalam mempengaruhi goncangan yang terjadi di negara benchmark, Singapura.

Model yang digunakan dalam penelitian ini terdiri dari tiga model, yaitu model Indeks Harga Konsumen (IHK), Model GDP Riil dan model Neraca Perdagangan.

$$
\begin{array}{rlr}
\text { IHKsgp }= & \beta 0+\beta 1 \mathrm{IHKbrunei} & +\beta 2 \mathrm{IHKkbj} \\
& +\beta 3 \mathrm{IHKindo} & +\beta 4 \mathrm{IHKlaos}
\end{array}
$$

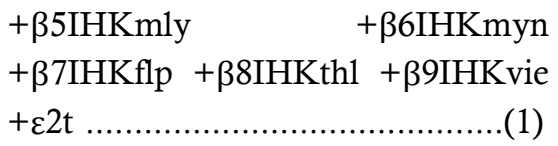

$$
\begin{aligned}
& \text { GDPsgp }=\beta 0+\beta 1 \text { GDPbrunei }+\beta 2 \text { GDPkbj } \\
& +\beta 3 \text { GDPindo } \quad+\beta 4 \text { GDPlaos } \\
& +\beta 5 \text { GDPmly }+\beta 6 \text { GDPmyn }+\beta 7 \text { GDP } \\
& \text { flp }+\beta 8 \text { GDPthl }+\beta 9 \text { GDPvie }+\varepsilon 1 t \ldots \text { (2) } \\
& \text { NPsgp }=\beta 0+\beta 1 \mathrm{NPbrunei}+\beta 2 \mathrm{NPkbj} \\
& +\beta 3 \text { NPindo }+\beta 4 \text { NPlaos }+\beta 5 \mathrm{NPmly} \\
& +\beta 6 \text { NPmyn }+\beta 7 \text { NPflp }+\beta 8 \text { NPth } \\
& 1+\beta 9 \mathrm{NPvie}+\varepsilon 3 \mathrm{t}
\end{aligned}
$$

Metode pengujian yang digunakan untuk uji stasioneritas adalah uji Philips-Perron dengn tingkat taraf nyata sepuluh persen. Apaila nilai tPP lebih negatif dibandingkan nilai kritis Mac Kinnon, maka data tersebut telah stasioner (tidak mengandung akar unit).

Tabel 1. Hasil Pengujian Akar Unit IHK

\begin{tabular}{lcccc}
\hline Variabel & \multicolumn{2}{c}{ Nilai PP } & \multicolumn{2}{c}{$\begin{array}{c}\text { Nilai Kritis MacKinnon } \\
\text { (taraf nyata 10 \%) }\end{array}$} \\
& Level & First Difference & Level & First Difference \\
\hline Brunei & -1.196039 & -7.219121 & -3.175693 & -3.176618 \\
Darussalam & & & & \\
Kamboja & -2.096511 & -4.723284 & 3.175693 & -3.176618 \\
Indonesia & -2.772995 & -7.381248 & -3.175693 & -3.176618 \\
Laos & -2.933379 & -6.310469 & -3.175693 & -3.176618 \\
Malaysia & -3.095050 & -6.796016 & -3.175693 & -3.176618 \\
Myanmar & -1.819642 & -4.234936 & -3.175693 & -3.176618 \\
Filipina & -2.366605 & -4.436519 & -3.175693 & -3.176618 \\
Singapura & -1.988212 & -4.555253 & -3.175693 & -3.176618 \\
Thailand & -1.675194 & -6.517450 & -3.175693 & -3.176618 \\
Vietnam & -2.224276 & -3.260420 & -3.175693 & -3.176618 \\
\hline
\end{tabular}

Sumber : IFS, data diolah 
Tabel 1 menunjukkan data IHK tidak stasioner pada tingkat level sehingga perlu dilakukan pengujian pada tingkat first difference. Pada uji first difference, semua data IHK telah stasioner.

Tabel 2. Hasil Pengujian Akar Unit GDP Riil

\begin{tabular}{|c|c|c|c|c|}
\hline \multirow[t]{2}{*}{ Variabel } & \multicolumn{2}{|l|}{ Nilai PP } & \multicolumn{2}{|c|}{$\begin{array}{l}\text { Nilai Kritis MacKinnon } \\
\text { (taraf nyata } 10 \% \text { ) }\end{array}$} \\
\hline & Level & First Difference & Level & First Difference \\
\hline Brunei Darussalam & -4.050384 & -20.25995 & -3.175693 & -3.176618 \\
\hline Kamboja & -3.099389 & -10.42669 & -3.175693 & -3.176618 \\
\hline Indonesia & -3.689613 & -9.022273 & -3.175693 & -3.176618 \\
\hline Laos & -2.675921 & -5.244620 & -3.175693 & -3.176618 \\
\hline Malaysia & -3.463189 & -4.522068 & -3.175693 & -3.176618 \\
\hline Myanmar & -2.921882 & -3.854910 & -3.175693 & -3.176618 \\
\hline Filipina & -3.506192 & -7.114392 & -3.175693 & -3.176618 \\
\hline Singapura & -3.517651 & -6.947505 & -3.175693 & -3.176618 \\
\hline Thailand & -4.659222 & -9.444732 & -3.175693 & -3.176618 \\
\hline Vietnam & -1.651474 & -3.910319 & -3.175693 & -3.176618 \\
\hline
\end{tabular}

Sumber : IFS, data diolah

Tabel 2 menunjukkan hasil akar unit variabel GDP Rill telah menunjukkan data GDP Rill tidak stasioner pada tingkat level. stasioner.

Kemudian setelah dilakukan pengujian pada first difference,

Tabel 3. Hasil Pengujian Akar Unit Neraca Perdagangan

\begin{tabular}{|c|c|c|c|c|}
\hline \multirow[t]{2}{*}{ Variabel } & \multicolumn{2}{|l|}{ Nilai PP } & \multicolumn{2}{|c|}{$\begin{array}{l}\text { Nilai Kritis MacKinnon } \\
\text { (taraf nyata } 10 \% \text { ) }\end{array}$} \\
\hline & Level & First Difference & Level & $\begin{array}{l}\text { First } \\
\text { Difference }\end{array}$ \\
\hline Brunei Darussalam & 0.266606 & -3.642433 & $-` 3.175693$ & -3.176618 \\
\hline Kamboja & -2.129310 &.-4.297558 & $-` 3.175693$ & -3.176618 \\
\hline Indonesia & -3.139382 & -9.406059 & -3.175693 & -3.176618 \\
\hline Laos & -0.906062 & -7.387957 & -3.175693 & -3.176618 \\
\hline Malaysia & -3.067648 & -16.76453 & -3.175693 & -3.176618 \\
\hline Myanmar & -3.968852 & -26.33621 & -3.175693 & -3.176618 \\
\hline Filipina & -5.154612 & -14.42384 & -3.175693 & -3.176618 \\
\hline Singapura & 3.394968 & -9.359715 & -3.175693 & -3.176618 \\
\hline Thailand & -2.878527 & -10.02915 & -3.175693 & -3.176618 \\
\hline Vietnam & $-3,467295$ & -16.54306 & -3.175693 & -3.176618 \\
\hline
\end{tabular}

Sumber : IFS, data diolah

Tabel 3 menunjukkan hasil uji akar unit neraca perdagangan pada tingkat level masih mengandung akar unit sehingga perlu dilakukan pengujian pada tingkat first difference. Hasil uji pada tingkat first difference menunjukkan data telah stasioner. Kriteria penentuan lag optimal ditentukan berdasarkan lag terpendek dan standar Akaike Information Criterion (AIC) yang terkecil. Hasil lag AIC yang terendah merupakan lag yang paling 
optimal, sehingga lag tersebut yang kan digunakan dalam pengujian selanjutnya.

Tabel 4. Hasil Uji Panjang Lag IHK

\begin{tabular}{cl}
\hline Lag (Kuartal) & AIC \\
\hline 0 & 41.19949 \\
1 & 23.15694 \\
2 & 22.27929 \\
3 & 20.00838 \\
4 & $10.82942 *$
\end{tabular}

Tanda $\left(^{*}\right)$ menunjukkan angka AIC terkecil

Tabel 5. Hasil Uji Lag GDP Riil

\begin{tabular}{cl}
\hline Lag (Kuartal) & AIC \\
\hline 0 & 30.35468 \\
1 & 19.90739 \\
2 & 17.72761 \\
3 & 15.76176 \\
4 & $2.040727^{*}$ \\
\hline
\end{tabular}

Tanda $\left({ }^{*}\right)$ menunjukkan angka AIC terkecil

Tabel 6. Hasil Uji Lag Neraca Perdagangan

\begin{tabular}{cc}
\hline $\begin{array}{c}\text { Lag } \\
\text { (Kuartal) }\end{array}$ & AIC \\
\hline 0 & 162.1827 \\
1 & 153.2915 \\
2 & 152.5423 \\
3 & 148.9374 \\
4 & $139.9145^{*}$
\end{tabular}

Tanda $\left({ }^{\star}\right)$ menunjukkan angka AIC terkecil

Berdasarkan tabel 4,5 dan 6 hasil uji lag optimal berada pada lag keempat. Uji kointegrasi dilakukan berdasarkan data yang tidak stasioner pada level namun stasioner pada tingkat first difference disebabkan oleh data yang tidak stasioner akan meningkatkan potensi adanya hubungan kointegrasi antar variabel.

Selain itu, uji kointegrasi dilakukan untuk menetukan metode yang akan digunakan. Apabila terbukti terkointegrasi, maka metode yang digunakan adalah VECM sedangkan apabila tidak terkointegrasi, maka metode yang digunakan adalah VAR. Penelitian ini menggunakan uji kointegrasi Johansen.Uji kointegrasi dilakukan dengan melihat nilai estimasi trace statistic dibandingkan dengan nilai critical value. Penelitian ini menggunakan nilai kritis sebesar lima persen. Apabila nilai trace statistic lebih besar maka persamaan tersebut mengalami kointegrasi.

Tabel 7. Hasil Uji Kointegrasi IHK

\begin{tabular}{lll}
\hline $\begin{array}{l}\text { Trace } \\
\text { Statistic }\end{array}$ & $\begin{array}{l}\text { Critical } \\
\text { Value }\end{array}$ & Prob \\
\hline 390.1653 & 239.2354 & 0.0000 \\
270.2155 & 197.3709 & 0.0000 \\
199.4655 & 159.5297 & 0.0001 \\
137.5845 & 125.6154 & 0.0076 \\
95.76715 & 95.75366 & 0.0499 \\
62.36953 & 69.81889 & 0.1699 \\
37.98070 & 47.85613 & 0.3028 \\
25.55365 & 29.79707 & 0.1426 \\
15.35101 & 15.49471 & 0.0526 \\
6.214385 & 3.841466 & 0.0127 \\
\hline
\end{tabular}

Tabel 8. Hasil Uji Kointegrasi GDP Riil

\begin{tabular}{lll}
\hline $\begin{array}{l}\text { Trace } \\
\text { Statistic }\end{array}$ & $\begin{array}{l}\text { Critical } \\
\text { Value } \mathbf{0 . 0 5}\end{array}$ & Prob \\
\hline 384.3879 & 239.2354 & 0.0000 \\
271.9761 & 197.3709 & 0.0000 \\
179.6847 & 159.5297 & 0.0025 \\
129.5168 & 125.6154 & 0.0283 \\
86.14629 & 95.75366 & 0.1905 \\
51.16534 & 69.81889 & 0.5865 \\
31.63925 & 47.85613 & 0.6319 \\
17.26264 & 29.79707 & 0.6206 \\
\hline
\end{tabular}

Tabel 9. Hasil Uji Kointegrasi Neraca Perdagangan

\begin{tabular}{lll}
\hline $\begin{array}{l}\text { Trace } \\
\text { Statistic }\end{array}$ & $\begin{array}{l}\text { Critical } \\
\text { Value 0.05 }\end{array}$ & Prob \\
\hline 445.2608 & 239.2354 & 0.0000 \\
294.8975 & 197.3709 & 0.0000 \\
217.3542 & 159.5297 & 0.0000 \\
152.3415 & 125.6154 & 0.0004 \\
100.8828 & 95.75366 & 0.0212 \\
61.61468 & 69.81889 & 0.1891 \\
38.23685 & 47.85613 & 0.2918 \\
19.37294 & 29.79707 & 0.4663 \\
8.125679 & 15.49471 & 0.4521 \\
2.829205 & 3.841466 & 0.0926 \\
\hline
\end{tabular}


Berdasarkan tabel 7 , tabel 8 dan tabel 9 , ketiga model indikator ekonomi mengindikasikan kointegrasi. Hal ini dapat disimpulkan bahwa metode yang digunakan yaitu Vector Error Correction Model (VECM).

\section{HASIL DAN PEMBAHASAN}

Hasil estimasi jangka pendek pada variabel Indeks Harga Konsumen (IHK) menunjukkan bahwa kenaikan harga-harga yang terjadi di sembilan negara ASEAN tidak memiliki hubungan yang signifikan dengan inflasi yang terjadi di Singapura. Hal ini disebabkan oleh time-lag yang masih pendek sehingga belum menunjukkan hubungannya dengan Singapura. Sedangkan korelasi yang terjadi pada pertumbuhan GDP Riil Singapura ditunjukkan oleh negara Brunei Darussalam dan Malaysia.

Hal ini berarti bahwa gejolak pendapatan nasional di kedua negara tersebut dalam jangka pendek memiliki korelasi yang cukup kuat dengan gejolak pendapatan nasional yang terjadi di Singapura. Namun, pada hasil estimasi neraca perdagangan sama sekali tidak ada negara yang menunjukkan adanya korelasi dengan Singapura. Hal ini menunjukkan bahwa surplus ataupun defisit neraca perdagangan pada sembilan negara di kawasan ASEAN tidak akan berkaitan dengan kegiatan perdagangan di Singapura.

Berdasarkan hasil estimasi tersebut, baik dalam jangka panjang maupun dalam jangka pendek menunjukkan rendahnya korelasi pada indikator perekonomian di ASEAN dengan negara benchmark, Singapura. Rendahnya korelasi ini mengindikasikan kurangnya integrasi dan kerjasama yang kuat dalam kawasan regional ASEAN. Hal ini berarti bahwa integrasi ekonomi yang telah berjalan di ASEAN belum mencapai hasil yang maksimal meskipun pada saat ini, ASEAN telah mencapai tahap integrasi yang matang hingga membentuk Masyarakat Ekonomi ASEAN (MEA). Hal ini dibuktikan dengan data total perdagangan ASEAN yang menunjukkan bahwa ASEAN lebih banyak melakukan aktivitas perdagangan dengan negara-negara ekstra ASEAN atau non ASEAN. Kecenderungan semakin banyak negara ASEAN yang melakukan perdagangan dengan negara ekstra ASEAN ini sesuai dengan teori perdagangan internasional dimana negara akan mencari keuntungan dengan lebih banyak mengekspor barang yang memiliki nilai kerugian absolut kecil dan mengimpor barang yang memiliki kerugian absolut lebih besar. Hasil penelitian ini sesuai dengan penelitian yang dilakukan oleh Ridha Subagja dan Mubarok (2015) yang menyimpulkan bahwa korelasi dari indikator perekonomian antar negara di ASEAN sangat rendah. Hasil ini juga diperkuat dengan penelitian yang dilakukan oleh Mohseni dan Azali (2014) bahwa pembentukan mata uang tunggal akan membutuhkan banyak biaya dan sulit untuk dikembangkan karena korelasi yang rendah dan adanya perbedaan kebijakan moneter dari masing-masing negara.

Hubungan jangka panjang pada variabel Indeks Harga Konsumen (IHK) menunjukkan hasil bahwa dalam jangka panjang, terdapat tujuh negara yaitu Brunei Darussalam, Kamboja, Laos, Malaysia, Myanmar, Thailand dan Vietnam yang memiliki hubungan signifikan dengan Singapura. Sedangkan dua negara yaitu Indonesia dan Filipina tidak memiliki hubungan yang signifikan dengan Indeks Harga Konsumen (IHK) di Singapura. Hal ini berarti bahwa dalam jangka panjang, kenaikan harga yang terjadi di Indonesia dan Filipina tidak berkaitan dengan inflasi yang terjadi di Singapura.

Sedangkan hasil estimasi variabel GDP Riil negara ASEAN terhadap GDP Riil Singapura dalam jangka panjang menunjukkan hasil bahwa hanya Indonesia dan Malaysia yang tidak memiliki hubungan yang signifikan dengan pertumbuhan GDP Riil di Singapura. Fenomena kenaikan ataupun penurunan GDP Riil di kedua negara tersebut tidak berkaitan dengan GDP Riil Singapura. Selain GDP Riil, indikator ekonomi yang lain yaitu neraca perdagangan yang menunjukkan kondisi ekspor bersih dari masingmasing negara ASEAN.

Hasil estimasi jangka panjang neraca perdagangan menunjukkan bahwa terdapat dua negara yaitu Laos dan Myanmar yang kegiatan perdagangannya tidak memiliki hubungan dengan perdagangan Singapura. Hal ini menunjukkan bahwa gejolak perdagangan Laos dan Myanmar tidak memiliki korelasi yang kuat dengan gejolak perdagangan di Singapura.

Berdasarkan hasil tersebut, kondisi perekonomian ASEAN dalam jangka panjang 
menunjukkan hasil yang beragam dari tiap-tiap indikator ekonominya dan belum ada hubungan ataupun korelasi yang sama-sama kuat dari berbagai negara. Hasil ini bertentangan dengan teori optimum currency area (oca) yang menyatakan bahwa syarat pembentukan mata uang tunggal diantaranya adalah adanya korelasi yang kuat dari masingmasing negara anggota. Namun, hasil pengujian menggunakan Vector Error Correction Model (VECM) jangka panjang menunjukkan hasil yang belum sesuai dengan syarat tersebut. Korelasi yang rendah dalam jangka panjang mengindikasikan bahwa dalam regional ASEAN, keterkaitan dan integrasi yang ada belum berjalan dengan maksimal. Hasil penelitian ini sesuai dengan penelitian yang dilakukan oleh Subagja dan Mubarok (2015) yang menyatakan bahwa tidak ada variabel ekonomi yang memiliki hubungan atau korelasi yang sangat kuat antar negara ASEAN sehingga kapabilitas ASEAN untuk membentuk mata uang tunggal belum terpenuhi dan mata uang tunggal belum bisa dibentuk.

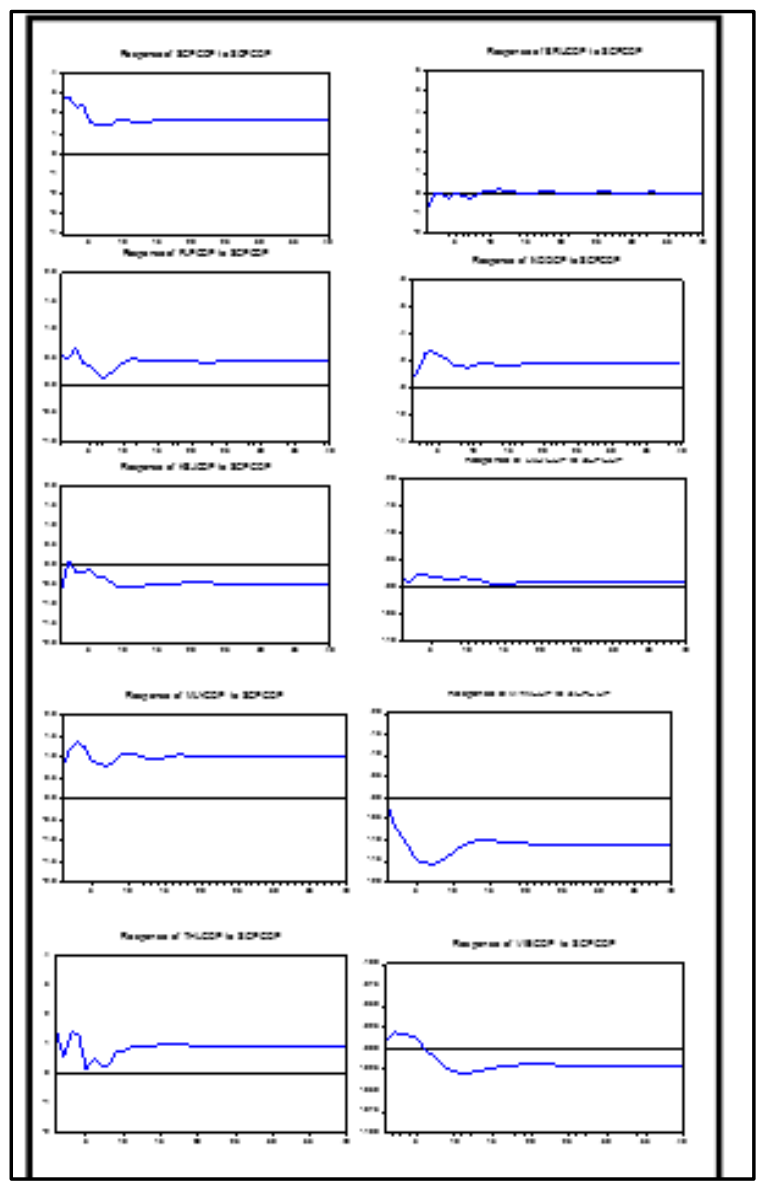

Gambar.1 Respon IHK Asean

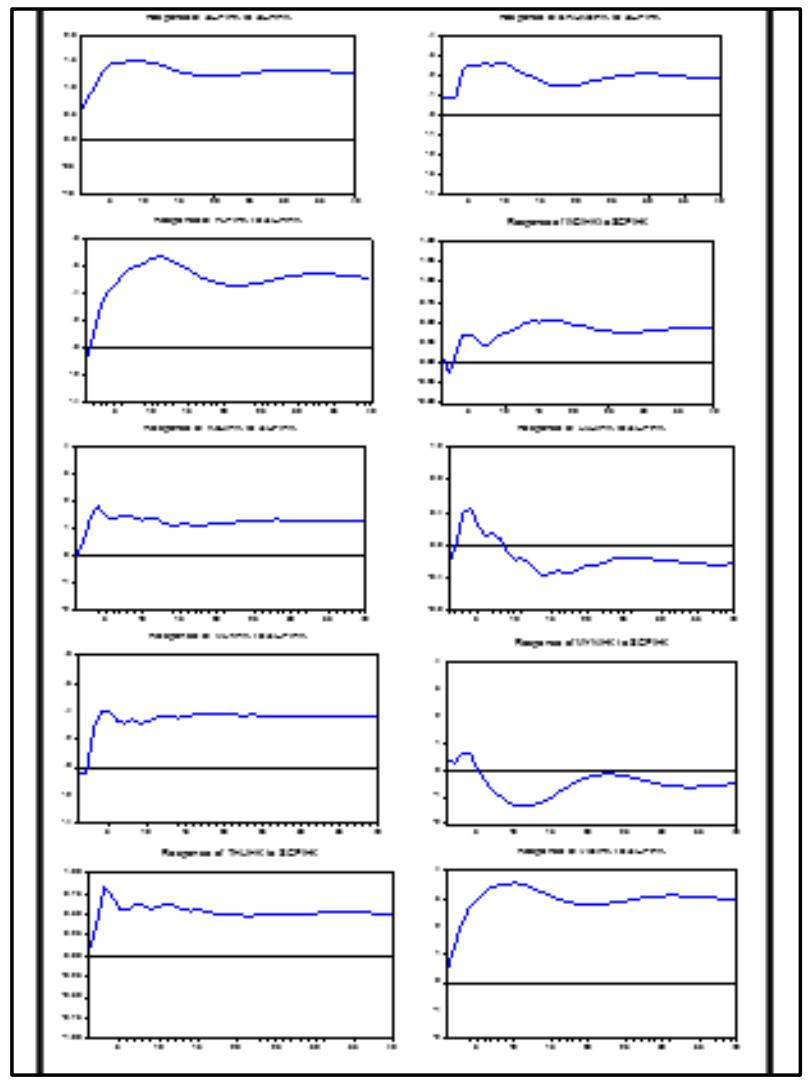

Gambar 2. Respon GDP Riil Asean

Hasil impulse response function menunjukkan respon goncangan dari seluruh negara ASEAN terhadap goncangan yang terjadi di Singapura. Negara yang memberikan respon positif terhadap goncangan inflasi di Singapura adalah Brunei Darussalam, Kamboja, Indonesia, Malaysia, Filipina, Singapura, Thailand dan Vietnam. Sedangkan negara yang merespon negatif adalah Laos dan Myanmar. Hasil ini mengindikasikan bahwa Indeks Harga Konsumen yang merupakan proksi dari kondisi inflasi di masing-masing negara ASEAN belum memiliki kesamaan pola guncangan

Hasil uji impulse response function pada neraca perdagangan ASEAN terhadap goncangan neraca di Singapura juga menunjukkan hasil yang belum simetris. Hal ini ditandai dengan adanya dua negara yang merespon negatif gejolak perdagangan di Singapura yaitu Filipina dan Thailand. Apabila Singapura mengalami kenaikan surplus neraca perdagangan, maka yang dialami oleh Filipina dan Thailand yaitu bertambahnya defisit neraca perdagangan. Hal ini berarti bahwa ketergantungan impor dengan Singapura pada kedua negara tersebut 
tinggi. Penyesuaian masing-masing negara ASEAN terhadap guncangan di Singapura membutuhkan waktu yang relatiflama. Hingga kuartal ke-40 masih terdapat negara dengan respon goncangan yang belum stabil.

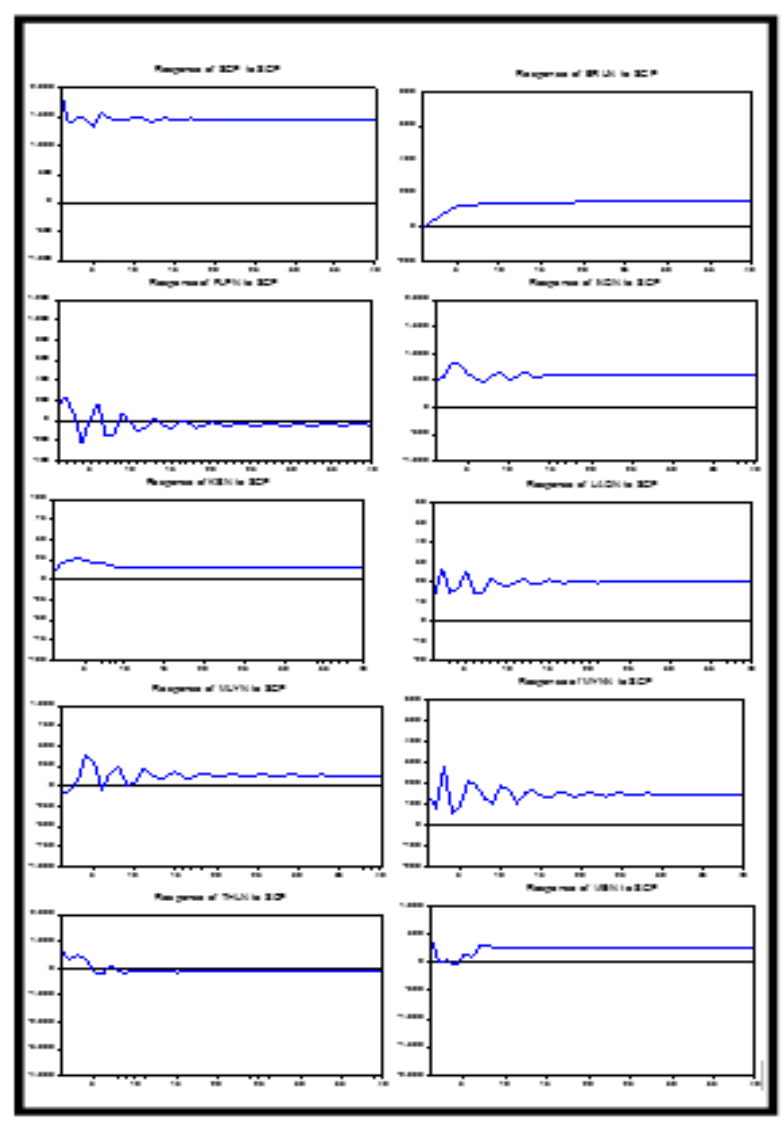

Gambar 3. Respon Neraca Perdagangan Asean

Teori Optimum Currency Area (OCA) menyebutkan bahwa salah satu syarat dari pembentukan mata uang tunggal adalah adanya kesamaan pola guncangan makroekonomi, namun apabila dilihat dari hasil impulse response function maka dapat disimpulkan bahwa negara ASEAN belum memenuhi syarat tersebut dari goncangan inflasi, GDP riil maupun neraca perdagangan. Goncangan asimetris yang terjadi di ASEAN ini sesuai dengan penelitian yang dilakukan oleh Kusuma dan Putranto (2010) yang menyatakan bahwa intensitas perdagangan merupakan salah satu penyebab variasi guncangan antar negara dalam regional. Intensitas perdagangan di ASEAN lebih banyak dilakukan dengan negara-negara ekstra ASEAN ditunjukkan dengan hasil korelasi antar negara ASEAN yang rendah. Selain itu adanya gangguan tak terduga juga dapat mempengaruhi output nasional suatu negara sehingga sebuah negara berbeda dengan yang lainnya (Frankel dan Musa,1980 dalam Kusuma dan Putranto, 2010).

Hasil variance decomposition variabel IHK menunjukkan kontribusi kondisi inflasi dalam suatu negara terhadap negara lain. Penelitian ini menunjukkan bahwa kondisi inflasi di Singapura dalam jangka waktu 5 tahun dan 10 tahun dipengaruhi oleh kondisi dari dalam negeri. Kondisi tersebut ditunjukkan oleh tingkat inflasi yang lebih stabil dan rendah dibandingkan dengan negara ASEAN lainnya. Tingkat inflasi yang rendah disebabkan oleh harga-harga komoditas yang cenderung stabil di Singapura. Hal ini disebabkan oleh perekonomian Singapura yang lebih kuat dan lebih maju dibandingkan negara ASEAN lainnya. Perekonomian yang kuat di Singapura dapat dilihat dari pendapatan nasional dan pendapatan perkapita masyarakatnya.

Berdasarkan hasil variance decomposition GDP Riil, kontribusi terhadap GDP Riil di Singapura justru berasal dari Negara Laos yang merupakan negara kecil dengan tingkat pendapatan perkapita rendah. Hal ini berarti berarti bahwa goncangan pendapatan nasional yang terjadi di Laos memberikan pengaruh yang lebih besar dibandingkan kondisi di Singapura itu sendiri. Kondisi ini disebabkan oleh adanya perjanjian kerjasama antara Laos dengan Singapura mengingat Laos merupakan jalur penghubung antara Singapura dengan China. Selain jalur penghubung Singapura dengan China, Laos memang negara penghubung negara-negara ASEAN dengan Tiongkok (landlink). Hal ini sesuai dengan teori pertumbuhan neo-klasik yang dikemukakan oleh Harrod-Domar yang berfokus kepada peranan investasi di dalam proses pertumbuhan ekonomi dimana investasi mampu menciptakan pendapatan dan investasi yang dapat memperbesar kapasitas produksi perekonomian dengan cara meningkatkan stok modal. 


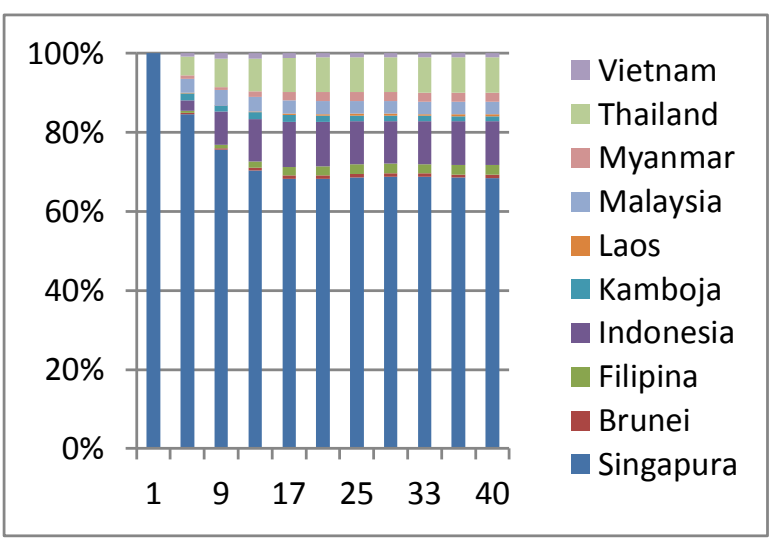

Gambar 4. FEVD IHK Asean

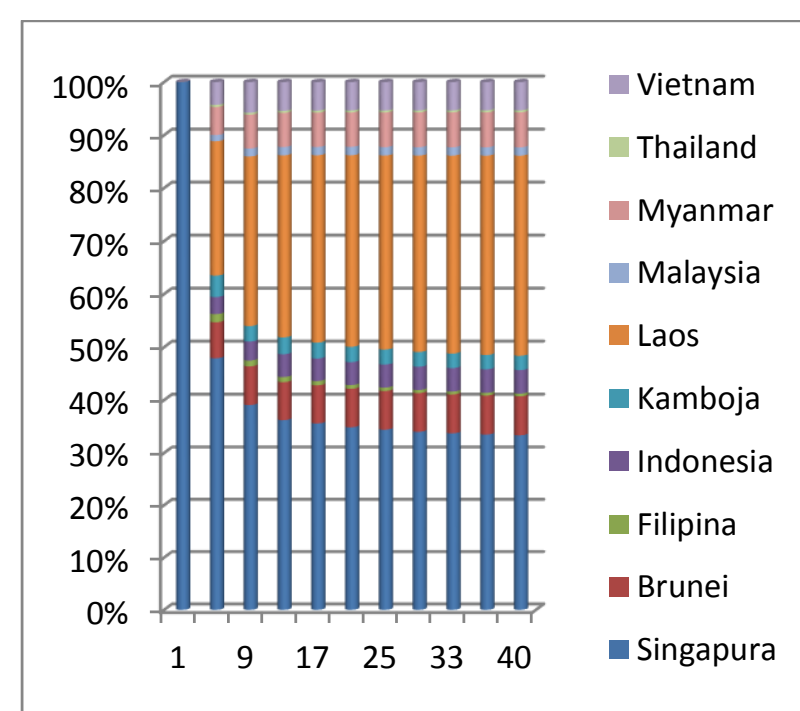

Gambar 5. FEVD GDP Riil Asean

Sedangkan hasil variance decomposition neraca perdagangan menunjukkan negara yang memberikan kontribusi tertinggi terhadap fluktuasi naik turunnya neraca perdagangan Singapura yaitu berasal dari goncangan internal Singapura.

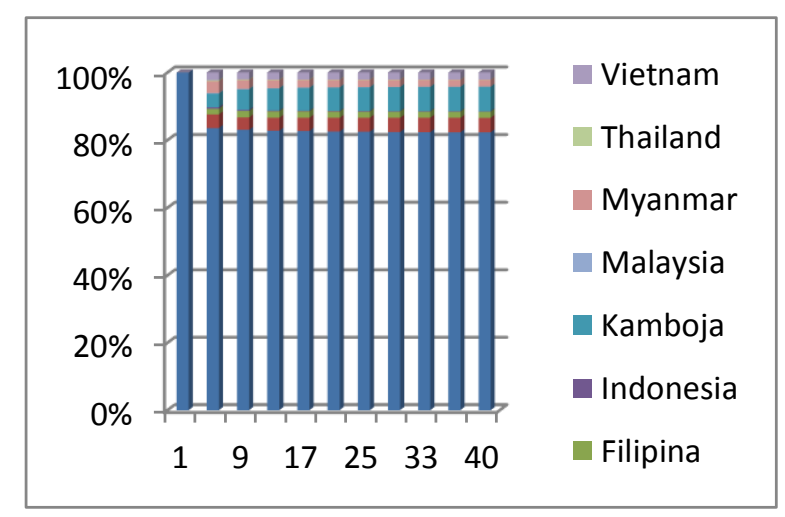

Gambar . FEVD Neraca Perdagangan Asean
Hasil variance docomposition menunjukkan bahwa dalam jangka waktu 5 tahun hingga 10 tahun, kondisi ekonomi yang terjadi di Singapura masih dominan dipengaruhi dari kondisi internal dalam negeri. Hal ini berarti kontribusi dan korelasi antar negara ASEAN masih rendah. Kondisi ini mengindikasikan kurangnya integrasi di ASEAN sehingga korelasi antar negara dan respon terhadap guncangan masih bersifat asimetris. Berdasarkan pemaparan hasil tersebut, kondisi variabel makroekonomi di ASEAN yaitu inflasi, GDP riil dan neraca perdagangan menunjukkan bahwa belum adanya kesamaan pola guncangan dan keterkaitan yang kuat dari masing-masing negara ASEAN. Selama jangka waktu 10 tahun, masih terdapat beberapa negara yang belum stabil dalam menghadapi goncangan yang terjadi di Singapura. Hal tersebut mengindikasikan bahwa ASEAN belum mampu mengontrol perekonomian di masing-masing negara. Hal ini sesuai dengan penelitian Kusuma dan Putranto (2010) yang menyimpulkan bahwa negara ASEAN tidak sesuai membentuk sebuah serikat moneter dibawah konsep optimum currency area sehubungan dengan peleburan guncangan asimetris. Selain itu, penelitian yang dilakukan oleh oleh Mohseni dan Azali (2014) menyimpulkan bahwa area yang belum mengalami guncangan secara simetris tidak dapat diterapkan mata uang tunggal. Negara-negara tersebut harus memperbaiki keadaan ekonominya untuk bergabung dan membentuk mata uang tunggal. Oleh karena, itu dalam jangka waktu 10 tahun ASEAN belum dapat menerapkan mata uang tunggal karena salah satu syarat dari Teori Optimum Currency Area (OCA) belum dapat terpenuhi.

\section{SIMPULAN}

Berdasarkan penjelasan di atas, kesimpulan penelitian ini adalah respon guncangan yang terjadi di ASEAN-10 dari indikator IHK, GDP Riil dan Neraca Perdagangan masih menunjukkan hasil yang beragam atau belum simetris. Selain itu, masing-masing negara di Asean belum mampu menunjukkan keterkaitan yang optimal. Hal ini mengindikasikan korelasi yang rendah disebabkan belum optimalnya integrasi di dalam kawasan 
Asean itu sendiri. Fenomena yang terjadi di Asean ini belum sesuai dengan kriteria teori optimum currency area sehingga pembentukan mata uang tunggal di Asean belum dapat dilakukan hingga sepuluh tahun ke depan. Perlu adanya penguatan kerjasama perdagangan dan keterbukaan intraASEAN..

\section{DAFTAR PUSTAKA}

Achsani, Noer Azam, dkk. (2013). The Feasibility of ASEAN+6 Single Currency : A Vector Error Currency Area dengan Menggunakan Model Vector Error Correction. Buletin Ekonomi Moneter, April 2010. Jakarta : Bank Indonesia

ASEAN Secretariat. (2016). ASEAN Statistical Yearbook 2015. Jakarta : ASEAN

Direktorat Jenderal Pengembangan Ekspor Nasional. (2015). Peluang dan Tantangan Indonesia Pasar Bebas ASEAN, Warta Ekspor Edisi Januari 2015. Jakarta : Kementerian Perdagangan RI

Falianty, Telisa Aulia. (2006). Endogenitas dari Indikator Optimum Currency Area : Studi Empiris di Negara ASEAN. Jurnal Ekonomi dan Pembangunan Indonesia Vol. VI No.02, 2006 Januari hal 1-28. Depok : Universitas Indonesia

Harahap,Siti Romida. (2013). Deteksi Dini Krisis Nilai Tukar Indonesia : Identifikasi Variabel Makro Ekonomi. Journal of Economics and Policy. Jejak 6 (1) (2013):17-18. Semarang : Universitas Negeri Semarang

Kusuma, Dimas Bagus Wiranata dan Arief Dwi Putranto. (2010). Penerapan Kriteria Optimum Currency Area dan Volatilitasnya : Studi Kasus ASEAN5+3. Buletin Ekonomi Moneter dan Perbankan. Malaysia : International Islamic University Malaysia
Corection Model. ASEAN Journal of Economics, Management and Accounting1 (1): 23-47. Bogor : Bogor Agricultural University

Alvarado, Sylvia. (2014). Analysis of the Optimum Currency Area for ASEAN and ASEAN +3. Journal of US-China Public Administration, Vol 11, No 12,995-1004. Ecuador : Universidad Andina Simon Bolivar

Ariefianto Moch Doddy dan Perry Warjiyo. (2010). Pergerakan Bersama Mata Uang ASEAN 4 Periode 1997-2005 : Suatu Aplikasi Teori Optimal

Kusuma, Dimas Bagus Wiranata.,dkk. (2013). The Role of ASEAN Exchange Rate Unit (AERU) for ASEAN-5 Monetary Integration : An Optimum Currency Area Criteria. Buletin Ekonomi Moneter dan Perbankan. Jakarta : Bank Indonesia

Mohseni, Reza Moosavi dan M. Azali. (2014). Monetary Integration and Optimum Currency Area in ASEAN+3: What We Need foa a New Framework ?. International Journal of Economics and Financial Issues Vol. 4 No 2, 2014, pp.277-285. Selangore : Universiti Putra Malaysia

Setiawan, Rifky Yudi dan Karsinah. (2016). Mekanisme Transmisi Kebijakan Moneter Dalam Mempengaruhi Inflasi dan Pertumbuhan Ekonomi di Indonesia. Economics Development Analysis Journal. EDAJ 5 (4)(2016). Semarang : Universitas Negeri Semarang

Subagja, Ridho dan Syahid Irfan Mubarok. (2015). Analisis Kapasitas Ekonomi Negara-Negara Anggota ASEAN dalam Rencana Pembentukan Mata Uang Bersama. Kajian Vol.20 No. 3 September 2015 hal. 241-254. Bandung : Universitas Padjajaran. 